\title{
Ventilator-associated pneumonia related to surveillance cultures and bronchoalveolar lavage
}

Citation for published version (APA):

Scholte, J. B. J. (2016). Ventilator-associated pneumonia related to surveillance cultures and bronchoalveolar lavage. [Doctoral Thesis, Maastricht University]. Datawyse / Universitaire Pers Maastricht. https://doi.org/10.26481/dis.20160128js

Document status and date:

Published: 01/01/2016

DOI:

10.26481/dis.20160128js

Document Version:

Publisher's PDF, also known as Version of record

\section{Please check the document version of this publication:}

- A submitted manuscript is the version of the article upon submission and before peer-review. There can be important differences between the submitted version and the official published version of record.

People interested in the research are advised to contact the author for the final version of the publication, or visit the DOI to the publisher's website.

- The final author version and the galley proof are versions of the publication after peer review.

- The final published version features the final layout of the paper including the volume, issue and page numbers.

Link to publication

\footnotetext{
General rights rights.

- You may freely distribute the URL identifying the publication in the public portal. please follow below link for the End User Agreement:

www.umlib.nl/taverne-license

Take down policy

If you believe that this document breaches copyright please contact us at:

repository@maastrichtuniversity.nl

providing details and we will investigate your claim.
}

Copyright and moral rights for the publications made accessible in the public portal are retained by the authors and/or other copyright owners and it is a condition of accessing publications that users recognise and abide by the legal requirements associated with these

- Users may download and print one copy of any publication from the public portal for the purpose of private study or research.

- You may not further distribute the material or use it for any profit-making activity or commercial gain

If the publication is distributed under the terms of Article $25 \mathrm{fa}$ of the Dutch Copyright Act, indicated by the "Taverne" license above, 
Summary 


\section{Summary}

The aims of this thesis were to explore the potential usefulness of surveillance cultures (SCs) in the intensive care unit (ICU) and to unravel different diagnostic aspects of ventilator-associated pneumonia (VAP). This was achieved by studying the results of SCs of predominantly endotracheal aspirates as well as corresponding and less commonly available bronchoalveolar lavage fluid (BALF) results.

In order to obtain more information about the potential usefulness of SCS, a review of the literature was conducted (Chapter 2 ) and a questionnaire was distributed among heads of all ICUs in the Netherlands as well as consultant medical microbiologists (Chapter 3). The review revealed that no randomized controlled trials were conducted regarding the usefulness of these cultures and that only several quasi-experimental and heterogeneous studies exploring the role of SCs in VAP antibiotic guidance and multidrug-resistant (MDR) management were available. The questionnaire was filled out and returned by a significant percentage of respondents, hence providing a reliable view in the Dutch ICU situation. According to the results of this questionnaire, SCs are routinely obtained in more than $70 \%$ of the ICUs, significantly more often in higher level ICUs. Treatment optimization of the individual patient was the most important reason to obtain SCs according to the respondents. Whereas the microorganisms identified by SCs were generally targeted in case the patient suffered from infection with an (yet) unknown source, a consensus was lacking whether to target microorganisms identified by these cultures when the infection source was not located at the sampled site. Although strong evidence concerning the usefulness of SCs implementation is thus lacking, both the review's and the questionnaire's findings indicate that the obtained endotracheal aspirate SCs could be helpful in daily patient care. Yet, their usefulness strongly varies according to patient population, the (associated) prevalence of MDR microorganisms, specific clinical conditions related to the institution, and local practices including selective decontamination use.

Concerning the diagnostic aspects of VAP, both her clinical definition and her diagnostic approach lack an internationally accepted consensus (Chapter 1). Ventilator-associated pneumonia is less and less frequently diagnosed, which could be due to the current profound implementation of VAP-preventing strategies. Nevertheless, other, comparable, diagnosis are now more often determined instead of VAP, which artificially and perhaps incorrectly lowers the VAP incidence. Regarding the diagnostic aspects of VAP potentially pathogenic microorganisms revealed by all (surveillance) cultures of endotracheal aspirates obtained in 2007 and 2012 in two nearby large teaching hospitals were analysed (Chapter 4). In addition, the concordance between two frequently used diagnostic modalities was analysed in 311 VAP-suspected cases (Chapter 5). Hence, prospectively collected BALF results and retrospectively collected results of paired endotracheal aspirate analysis obtained within two days before or one day after the bronchoalveolar lavage from an 8-year period were included. 
In total 4,184 potentially pathogenic microorganisms were identified in 2007 and 2012 in the two nearby hospitals. These microorganisms, including their antibiotic susceptibility analysis results, were arranged according to the number of days after hospitalisation they were obtained. A fundament to classify VAP according to the time of onset could neither be found from an aetiological nor from a therapeutic point of view. Consequently, the classically used terms 'early-onset' and 'late-onset' VAP can probably be abandoned from contemporary medicine. When the calculated antibiotic susceptibility of these potentially pathogenic microorganisms is interpreted as the appropriateness of this specific antibiotic for VAP, the appropriateness of frequently used empirical antibiotics rapidly decreases below an unacceptable $70 \%$ in the course of hospital admission. This indirectly emphasises the usefulness of SCs, as a specific antibiotic will not be administered when microorganisms previously identified by SCS appeared not to be susceptible to that antibiotic. As resistance to frequently used antibiotics appears to rise and resistance to infrequently used antibiotics appears to fade away, antibiotic cycling or -rotation may be useful in future empirical VAP management.

In the concordance analysis, VAP incidences in the analysed population immensely varied from $15 \%$ up to $68 \%$ depending on the diagnostic tests used and their predefined thresholds for positivity. The Gram stain and culture results of the endotracheal aspirates and the BALF were only fairly in accordance and are therefore probably not interchangeable in the diagnostic approach of VAP. These results are relevant and in contrast to what is suggested by the authoritative guidelines which state that VAP can be diagnosed using either endotracheal aspirate analysis or BALF analysis.

In the penultimate part of the thesis, BALF results of yet unknown significance were explored. Commensal oropharyngeal microbiota is frequently identified in respiratory samples and this finding is generally regarded irrelevant. Stenotrophomonas maltophilia is a notorious MDR microorganism that is increasingly identified in the ICU and, similar to commensal oropharyngeal microbiota, frequently regarded irrelevant. It was often considered impossible for these bacteria to cause VAP. Hence, VAP suspected patients with merely $10^{4}$ or more cfu of these microorganisms per $\mathrm{ml} \mathrm{BALF}$ on culture were subsequently analysed. The commensal oropharyngeal microbiota cases were compared to a reference group (Chapter 6 ) and the S. maltophilia cases were matched to cases with a VAP caused by other nosocomial Gram-negative microorganisms (Chapter 7). Approximately $9 \%$ of all VAPs appeared to be caused by commensal oropharyngeal microbiota, whereas $1.8 \%$ was caused by $S$. maltophilia. Probably, these frequently considered nonpathogenic microorganisms became pathogenic resulting in VAP due to the immunocompromised status of the critically ill patient. 
Samenvatting 


\section{Samenvatting}

De doelen van dit proefschrift waren om het potentiële nut van surveillance kweken (= surveillance cultures [SCs]) op de intensive care afdeling (= intensive care unit [ICU]) te achterhalen en om enkele onduidelijke diagnostische aspecten van een beademinggerelateerde longontsteking (= ventilator-associated pneumonia [VAP]) op te helderen. Dit werd bereikt door het bestuderen van SC uitslagen van met name endotracheale aspiraten en de hiermee overeenkomende uitslagen van een bronchoalveolaire lavage vloeistof (= bronchoalveolar lavage fluid [BALF]) analyse. Tevens werden enkele minder gebruikelijke uitslagen van BALF analyse uitgeplozen.

Om het potentiële nut van SCs te ontraadselen werd een literatuurstudie verricht (Hoofdstuk 2) en een vragenlijst verspreid onder de hoofden van alle Nederlandse ICUs en medisch microbiologen (Hoofdstuk 3). Er bleken nog nooit gerandomiseerde gecontroleerde onderzoeken gedaan te zijn naar het nut van SCs. De studies die de rol van SCs in VAP en/of antibiotica resistentie beschreven, bleken veelal quasiexperimenteel en heterogeen. De vragenlijst werd door velen ingevuld en teruggestuurd waarbij de resultaten een betrouwbaar beeld van de Nederlandse situatie geven. Surveillance kweken worden volgens de respondenten standaard afgenomen in ongeveer driekwart van alle Nederlandse ICUs en significant vaker in de grotere ICUs. De meest aangegeven reden om SCs te verrichten was de betere behandeling van de individuele patiënt. De micro-organismen welke geïdentificeerd werden door SCs worden in de meeste ICUs bestreden wanneer de patiënt een infectie ontwikkelt waarbij de bron (nog) onbekend is. Echter, wanneer de (vermeende) infectiebron zich niet op dezelfde plaats bevindt waar de positieve SC werd afgenomen, bestaat er grote variatie in het antwoord op de vraag of de door SCs geïdentificeerde micro-organismen bestreden dienen te worden. Hoewel er dus geen eenduidig wetenschappelijk bewijs bestaat, kunnen SCs van endotracheale aspiraten potentieel nuttig zijn in de dagelijkse patiëntenzorg volgens zowel de vragenlijst als de literatuurstudie. Het potentiële nut van deze SCs is daarbij sterk afhankelijk van de patiëntenpopulatie en de hierbij samenhangende prevalentie van bijzonder resistente micro-organismen, specifieke eigenschappen van de betreffende ICU en ziekenhuis en lokale protocollen inclusief het toepassen van selectieve decontaminatie.

Aangaande de onduidelijke diagnostische aspecten van VAP, bestaat er geen internationaal geaccepteerde consensus over zowel de klinische definitie als over welke manier van diagnosestelling de voorkeur geniet (Hoofdstuk 1). Beademinggerelateerde longontsteking wordt tegenwoordig steeds minder vaak gediagnostiseerd, hetgeen mogelijk te danken is aan de goede uitvoering van de klassieke VAP-preventie maatregelen. Een aantal op VAP gelijkende ziektebeelden wordt echter tegenwoordig steeds frequenter gediagnosticeerd. Dit laatste zou kunnen suggereren dat de VAP incidentie kunstmatig en daarmee dus onterecht is gedaald. Ten aanzien van deze diagnostische onduidelijkheden werden alle potentieel pathogene micro-organismen 
welke geïdentificeerd werden in alle (surveillance) kweken van endotracheale aspiraten in 2007 en 2012 in twee nabijgelegen ziekenhuizen geanalyseerd (Hoofdstuk 4). Tevens werd de overeenstemming tussen twee veelgebruikte diagnostische onderzoeken onderzocht bij 311 van VAP verdachte patiënten. Hiertoe werden alle gedurende 8 jaar prospectief verzamelde BALF resultaten van VAP verdachte patiënten vergeleken met de resultaten van gepaarde endotracheale aspiraten welke verkregen waren tussen 2 dagen vóór tot 1 dag na de BALF afname (Hoofdstuk 5).

In de nabijgelegen ziekenhuizen werden in 2007 en 2012 in totaal 4.184 potentieel pathogene micro-organismen geïdentificeerd door de (surveillance) kweken. De microorganismen werden, tezamen met hun antibiotica-gevoeligheid, geordend naar het aantal dagen na ziekenhuisopname dat de kweek was afgenomen. Noch vanuit een etiologische noch vanuit een therapeutische basis kon beargumenteerd worden VAP in te delen op basis van ontstaanstijd in relatie met ziekenhuisopname. Dientengevolge kunnen de veelgebruikte en onduidelijke termen 'vroege' en 'late' VAP waarschijnlijk worden verbannen uit de hedendaagse geneeskunde. Wanneer de berekende antibiotica gevoeligheid van de geïdentificeerde potentiële pathogene microorganismen zou worden geïnterpreteerd als geschiktheid van dit specifieke antibioticum voor VAP, zou de geschiktheid van veelgebruikte antibiotica gedurende het verloop van ziekenhuisopname snel onder een onacceptabele $70 \%$ komen. Deze bevinding onderstreept indirect het belang van SCs, omdat een patiënt waarbij te voren in SCs een micro-organisme is geïdentificeerd welke resistent is tegen een bepaald antibiotica, niet met dit specifieke antibioticum behandelend zal gaan worden in geval van een (vermoeden op) een bacteriële infectie. De resistentie tegen veel gebruikte antibiotica lijkt toe te nemen terwijl de resistentie tegen minder frequent gebruikte antibiotica lijkt af te nemen. Dit fenomeen zou kunnen pleiten om steeds weer andere empirische antibiotica te gebruiken.

In de studie waarbij naar de overeenkomsten tussen de resultaten van BALF en endotracheale aspiraten gekeken werd, varieerde de VAP incidentie in deze gelijkblijvende populatie tussen $15 \%$ en $68 \%$, afhankelijk van welke diagnostische test en afkappunt voor de diagnose VAP gebruikt werd. De resultaten van Gram kleuring en kweken kwamen maar betrekkelijk met elkaar overeen. Hierdoor lijkt het erop dat het wel degelijk uitmaakt met welk diagnosticum een VAP wordt vaststelt. Dit is in tegenstelling tot hetgeen de gezaghebbende richtlijnen aangeven; namelijk dat het niet belangrijk is welk diagnosticum gebruikt wordt.

In het voorlaatste deel van dit proefschrift worden de BALF uitslagen met een nog onduidelijke betekenis geanalyseerd. Commensale keelmicrobiota wordt vaak geïdentificeerd in microbiologische monsters, hetgeen vervolgens meestal geïnterpreteerd wordt als een irrelevante bevinding. Stenotrophomonas maltophilia is een notoir MDR micro-organisme welke steeds vaker op de ICU wordt geïdentificeerd en meestal ook als onbelangrijk wordt beschouwd. Over het algemeen wordt verondersteld dat deze bacteriën niet in staat zijn een VAP te kunnen veroorzaken. 
Daarom werden alle van VAP verdachte patiënten met $10^{4}$ of meer kolonievormende eenheden van louter deze micro-organismen per $\mathrm{ml}$ BALF in de kweek uitgebreid onderzocht. De commensale keelmicrobiota groep werd vergelijken met een referentiepopulatie (Hoofdstuk 6) en elke S. maltophilia VAP patiënt werd vergelijken met 3 vergelijkbare patiënten met een VAP veroorzaakt door andere in het ziekenhuis opgelopen Gram negatieve bacil (Hoofdstuk 7). Ongeveer $9 \%$ van alle VAPs bleek te zijn veroorzaakt door commensale keelmicrobiota terwijl 1,8\% bleek te zijn veroorzaakt door S. maltophilia. Deze veelal niet pathogene beschouwde micro-organismen kunnen zich dus gedragen als ware ziekteverwekkers resulterende in een VAP, waarschijnlijk doordat de weerstand bij de ICU-patiënt verminderd is. 